\title{
"Local authorities and tourism: the role of regional tourist products in Poland"
}

\begin{tabular}{|c|c|}
\hline AUTHORS & $\begin{array}{l}\text { Bożena Sanetra } \\
\text { Sabina Sanetra-Półgrabi }\end{array}$ \\
\hline ARTICLE INFO & $\begin{array}{l}\text { Bożena Sanetra and Sabina Sanetra-Półgrabi (2019). Local authorities and } \\
\text { tourism: the role of regional tourist products in Poland. Tourism and Travelling, } \\
2(1), 16-23 \text {. doi:10.21511/tt.2(1).2019.03 }\end{array}$ \\
\hline DOI & http://dx.doi.org/10.21511/tt.2(1).2019.03 \\
\hline RELEASED ON & Wednesday, 19 December 2018 \\
\hline RECEIVED ON & Monday, 12 November 2018 \\
\hline ACCEPTED ON & Friday, 14 December 2018 \\
\hline LICENSE & $\begin{array}{l}(c) \text { EY-NO } \\
\text { This work is licensed under a Creative Commons Attribution-NonCommercial } 4.0 \\
\text { International License }\end{array}$ \\
\hline JOURNAL & "Tourism and Travelling" \\
\hline ISSN PRINT & 2544-2295 \\
\hline ISSN ONLINE & $2616-5090$ \\
\hline PUBLISHER & LLC "Consulting Publishing Company "Business Perspectives" \\
\hline FOUNDER & Sp. z o.o. Kozmenko Science Publishing \\
\hline $0^{0}$ & $\begin{array}{l}\text { ニこ: } \\
\text { 三こ: }\end{array}$ \\
\hline NUMBER OF REFERENCES & NUMBER OF FIGURES \\
\hline 23 & 1 \\
\hline
\end{tabular}

(C) The author(s) 2023. This publication is an open access article. 


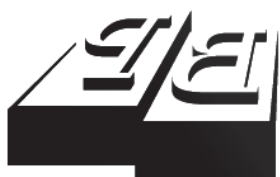

BUSINESS PERSPECTIVES

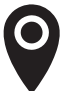

LLC "CPC "Business Perspectives" Hryhorii Skovoroda lane, 10, Sumy, 40022, Ukraine

www.businessperspectives.org

Received on: $12^{\text {th }}$ of November, 2018 Accepted on: $14^{\text {th }}$ of December, 2018

(C) Bożena Sanetra, Sabina SanetraPółgrabi, 2019

Bożena Sanetra, Ph.D., University of Economics and Humanities in Bielsko-Biała, Bielsko-Biała, Poland.

Sabina Sanetra-Półgrabi, Ph.D. Pedagogical University of Cracow, Cracow, Poland.

\section{(ㄷ)(1) $(8)$}

This is an Open Access article, distributed under the terms of the Creative Commons Attribution-NonCommercial 4.0 International license, which permits re-use, distribution, and reproduction, provided the materials aren't used for commercial purposes and the original work is properly cited.

\section{LOCAL AUTHORITIES AND TOURISM: THE ROLE OF REGIONAL TOURIST PRODUCTS IN POLAND}

\begin{abstract}
The article indicates the role of local authorities in influencing the development of tourism, including the creation of regional tourism products. The aim of paper is to define and characterize the capabilities of local authorities concerning the development of tourism, including legal, organizational, investment and promotional instruments. Also, the importance of regional tourism products was substantiated, including their structure, conditions and approaches to creation as well, as their role in regional development. The article is an introduction to in-depth research on the importance of regional tourism products in providing social and cultural security.
\end{abstract}

\section{Keywords local authorities, tourism, tourist product, tourist market, tourism development}

\section{JEL Classification L83, Z30, Z32}

\section{INTRODUCTION}

The need to launch new products creation is connected with the challenges at the tourist market. It is about adapting to the expectations of clients connected with the development of new forms of tourism and new ideas. Undoubtedly, the emergence of new products was affected by the general saturation with metropolitan tourism and the increase in the intensity of negative phenomena, as well as the emergence of several threats of different source. More and more are being written about the role of "alternative tourism", which is a response to the negative effects and the understanding of mass tourism, and in particular about the operation of tourist reception areas. It concerns education and promotion of local and regional tourism products targeted at small and family enterprises, as well as the development of home services, especially gastronomy. Emphasis is placed in particular on obtaining income for residents and municipalities, as well as flexible operation of the enterprise (Zdon-Korzeniowska, 2009).

Regional tourist products are spatially defined, equipped with unique, distinctive natural and anthropogenic attractions. Most often they are settlement units, usually rural communes and municipalities. Undoubtedly, in Poland, the functioning three-level structure of territorial self-government determines the nature and scope of the tasks carried out also in relation to tourism. It is an important branch of the economy, determining the broadly understood local development, the size of the labor market and the quality of life of residents. It is well known that, in addition to the increase in tourist traffic, local gastronomy, culture and other forms of entertainment are very good. Therefore, there is an issue of the influence of local authorities on the 
development of tourism and the characteristics of the tourist products. The aim of the article, apart from presenting the main directions of the influence of self-government authorities, is also to determine the nature and significance of regional tourist products, including conditions and ways of their creation. This paper indicates the nature of instruments, which are affected by local authorities in relation to regional tourist products, but it should be considered that tourism assets, their quantity, diversity and quality are of decisive importance. Another factor is national policy, access to finance and opportunities for cooperation with other market participants. This article is an introduction to the broad research concerning the role of regional tourist products in providing cultural and social security at the local level.

\section{THEORETICAL BASIS}

As part of the tasks assigned by the laws, local authorities have influence on the broadly understood development. Their role is very often overestimated, however, for many local government leaders, the use of local resources for tourism is an opportunity to develop other related industries. It is worth noting at the outset that apart from commune and district authorities, an important role in the implementation of tourism policy is carried out by entrepreneurs and tourist organizations in the site of tourist reception (accommodation, gastronomy, tourist carriers, tour operators), entrepreneurs and organizations belonging to the "complementing tourist economy" (souvenir producers, providers of publishing and cartographic services) as well as entrepreneurs and organizations belonging to the "indirect tourist economy" (providers of accompanying services, without which it would be difficult to develop tourism, including banks, insurance companies, etc.) (Drążkiewicz, 2009). These are only some of the entities that implement tourism policy in a given territory.

When analyzing the scope of impact of local authorities on the development of tourism, it seems undoubtful that some of the factors are of an independent nature, above all, they are tourist values, both those of a natural and anthropogenic nature. In addition, factors and directions of the national tourism policy, international impact, the situation in other regions of the world. However, the local level of the discussed area is also influenced by the closer environment, on which the local authorities have influence, it is about creating favorable institutional, financial and organizational conditions, as well as the impact on technical, social and economic infrastructure (see Table 1).

Table 1. Possible impact of local authorities on tourism development

Source: developed by the authors based on Zalech (2010).

\begin{tabular}{|c|c|c|c|}
\hline No. & Type of activity & Nature & $\begin{array}{l}\text { Role } \\
\end{array}$ \\
\hline 1 & Investment & $\begin{array}{l}\text { - } \quad \text { modernization of operations; } \\
\text { - } \quad \text { restructuring of operations; } \\
\text { revitalization of instruments }\end{array}$ & $\begin{array}{l}\text { introducing new elements of tourist } \\
\text { infrastructure; } \\
\text { adapting; } \\
\text { renewing the existing infrastructure of the } \\
\text { tourist market }\end{array}$ \\
\hline 2 & $\begin{array}{l}\text { Organizational } \\
\text { and human }\end{array}$ & $\begin{array}{l}\text { - } \quad \text { planning activities; } \\
\text { information activities }\end{array}$ & $\begin{array}{l}\text { Creating responsibility for coordination and } \\
\text { development of tourism; } \\
\text { organizing of training and conferences }\end{array}$ \\
\hline 3 & Popularizing & $\begin{array}{l}\text { - } \quad \text { promotional activities; } \\
\quad \text { territorial marketing }\end{array}$ & $\begin{array}{l}\text { active attracting of tourists and investors } \\
\text { from the tourism industry and related } \\
\text { sectors; } \\
\text { raising awareness of the benefits of tourism } \\
\text { development among residents }\end{array}$ \\
\hline 4 & Legal & $\begin{array}{l}\text { creating acts of local law; } \\
\text { taking advantageous location decisions; } \\
\text { developing the strategy (program) for tourism } \\
\text { development }\end{array}$ & $\begin{array}{l}\text { facilitating the conduct of various forms of } \\
\text { tourist and recreational activities; } \\
\text { determining the directions of tourism } \\
\text { development at the local level }\end{array}$ \\
\hline 5 & Offset (offer) & - $\quad$ preparing offers for investors & $\begin{array}{l}\text { facilitating the inflow of investments with a } \\
\text { certain value and specificity }\end{array}$ \\
\hline 6 & $\begin{array}{l}\text { In the communal } \\
\text { area }\end{array}$ & $\begin{array}{l}\text { development of technical infrastructure and } \\
\text { transport; } \\
\text { providing order and aesthetics }\end{array}$ & - $\quad$ creating an original and friendly tourist space \\
\hline
\end{tabular}


The above-mentioned set of instruments does not exhaust the entire set of activities and possibilities of influencing the development of tourism. One of the elements of the influence of local authorities on the analyzed area is cooperation with neighboring communes and districts (Basińska-Zych \& Lubowiecki-Vikuk, 2010). In this context, it is worth pointing out the role of border communes, which in the framework of euroregional cooperation or partnership projects implement many tourist initiatives, including the preparation of joint plans, strategies for creating cross-border tourist products. The examples include the Bieszczady Cross-Border Tourist Cluster (Sala, 2016), the Berlin-Szczecin-Baltic Sea water route Transborder Tourist Cluster or cross-border brands of the Polish-Czech borderland: "Citywalk" and "Fortfan", which are an example of the implementation of tourist ideas for network products (Krawczyszyn, 2011).

The indicated examples of tourist cross-border cooperation are characterized by a number of features, firstly they are based on natural and anthropogenic values of border areas that have been previously identified and selected by partners on both sides of the border, they refer to cultural and historical heritage and they integrate cities and communes situated in the border zone (Krawczyszyn, 2011).

Also, it should be emphasized that in defining the subject of market exchange, apart from the term "tourist product", other synonymous expressions are used, i.e. "territorial product", "mega product", "communal product", "product of the area", "product of the region, city or village" or "regional product", "regional tourist product" (ZdonKorzeniowska, 2009).

The presented terms indicate the territorial and spatial character of the tourist product. It is mainly about a specific "place", i.e. a settlement unit, creating a homogeneous organizational and spatial unit. With regard to marketing activities, such a place can be a separate area: of different size and spatial shape, employment level, functions, natural conditions, level of development, different time horizon of separation and activity, and compliance with spatial and administrative division, different management system, and internal division, similar degree of similarity to neighboring areas and a complex degree of institutionalization and formalization of functioning as well as the level of social identification in the country and abroad. In general, every place must be spatially identified, have institutions, i.e. first and foremost authorities and economic entities as well as NGOs, and have assigned tasks and funds for their implementation. It should be added that no spatial object is functioning in isolation, thus it is a system cooperating with other places (Szromnik, 2008).

When developing the issue of settlement units, to which the "regional tourism product" refers, it should be noted that the projects comprising territorial marketing are implemented primarily by: municipalities or their separate urban, administrative and functional parts, and thus: districts or housing estates, the main market, central business districts, main shopping street, historic cadastral unit, sports and recreation complex, other separate part. Tasks in the field of territorial marketing are also implemented by rural communes or their separate administrative and functional parts, i.e.: a sołectwo (sub-commune) or a group of sołectwo, a separate natural area, a separate functional area. In addition, specific activities may also be carried out by a group of municipalities and rural communes separated for administrative, economic or natural reasons. Other units in the internal hierarchy, whose activities are part of the marketing tasks are: districts or their parts and groups, as well as voivodeships or their parts. The following special spatial units of special socio-political, economic, natural, tourist and historical importance also deserve special attention: cross-border areas, special economic zones, technology parks, clusters, Euroregions, national and landscape parks, nature-historical parks, nature reserves, open-air museums, tourist stations, other legally protected areas of nature (Szromnik, 2008).

These entities constitute a whole set of spatial units, separated on the basis of different criteria, including geographical, natural, climatic, historical, economic and social issues. One should not forget about the regionalization introduced in Poland on January 1, 1999, based on the intra-regional hierarchy consisting in the separation of new voivodships, which are defined interchangea- 
bly as regions ${ }^{1}$. This administrative understanding coincides with the perception of a regional tourist product proposed by the authors locating the product in question between the local and national areas and attributing its range to the voivodeship, or a larger geographical, ethnographic and historical land (Kaczmarek et al., 2005; ZdonKorzeniowska, 2009).

Another important theoretical problem, in addition to the spatial location, when describing a regional tourist product is the indication of the components, attractions that it consists of. In general, the tourist value may take form of: landscape, healing properties of the climate, clean water, beaches, long-snowing on exposed slopes, architectural monuments, but also silence, peace, kindness of residents, entertainment, high level of services, etc. (Kruczek \& Sacha, 2001).

The exemplifications of particular types of values can be made using two criteria: genesis and function. The first group includes: natural (environmental) tourist values and cultural (anthropogenic) tourist values. Among the natural tourist assets that give the tourists full satisfaction, the climate, shape of the surface and natural resources are mentioned from the point of view of their role. A detailed list of these assets is made up of the following elements: lithosphere (land relief, natural peculiarities), atmosphere (air quality, snow cover, temperature), hydrosphere (rivers, streams, lakes, reservoirs, seas, mineral springs), soil cover (deserts), plant cover (forests, peculiarities of flora), animal world (fish, birds, protected species of fauna, game animals), natural landscape (conglomerates of the aforementioned elements of tourist values with high aesthetic values). Natural tourist values occur practically everywhere, although with varying intensity. At the same time, it should be noted that as a result of the instrumental relation of man to nature, the resources of tourist attractions are being reduced. For example, clean air and water, as well as various species of animals are nowadays increasingly rarer goods on the tourist market. Therefore, it is necessary to carefully and consistently protect natural tourist values (Gaworecki, 2003).
The group of cultural values includes the products of human labor as an element of tourist values which constitute an important tourist motivation. Kruczała proposes to divide these attractions into historical and contemporary ones (Kruczała, 1986; Gaworecki, 2003). Historical values include: historical places and places associated with significant events and outstanding people, architectural, urban planning and technical works, and their groups, archaeological sites and museum collections, places of religious worship. In the group of contemporary values, in turn, we have: outstanding economic works (e.g. new cities), interesting industrial objects, works of communication technology, large water structures, outstanding works of urban architecture, interesting objects of contemporary culture (theaters, galleries, exhibitions); large shopping and entertainment centers. This division can be treated as a conventional one, due to the fact that, for example, a cultural landscape with significant aesthetic qualities contains both historical and contemporary elements (Kruczała, 1986; Gaworecki, 2003).

On the other hand, the division considering the above functional criterion distinguishes the leisure, specialist and sightseeing qualities. The first one is the basis for the development of recreational functions and remains strictly dependent on the conditions of the natural environment. In turn, specialist qualities are associated with features of environmental elements enabling the cultivation of various forms of qualified and active tourism, and in the case of presence of mineral waters and favorable climatic conditions in any area - they form the basis for the development of spa functions. The last of the indicated, the sightseeing quality, is the object of cognitive interest and the basis for the development of the "sightseeing function" of areas or localities. A distinction is made between landscape qualities of the natural environment, which include characteristic landscape complexes, natural curiosities, including nature monuments, reserves, national parks, etc., and touristic or cultural qualities that include elements of material and spiritual culture, including monuments, folklore, objects of national cult and

1 The process of regionalization performed in Poland, i.e. the activity or effect, consisted in reducing the number of voivodeships from 49 to 16 and restoring the self-government at the district and voivodeship level. In general, voivodeships have been identified with regions, i.e. units having, apart from the territory, also population, electoral authorities, budget and legal personality. In addition, the community living in the region is connected by a community of fate, tradition, culture and the presence of an economic homogeneity (Herc, 2013). 
objects related to contemporary human achievements (Kruczek \& Sacha, 2001).

Another author, Gaworecki, emphasizes that the element characteristic for the basic tourist attractions (tourist qualities) are historic-cultural, entertainment, recreational and health qualities. They are distinguished by historical and cultural monuments, museums, architecture, folklore, legends and fairy tales related to a given area, bathing areas, mineral water springs, beaches, sports and leisure facilities, etc. (Gaworecki, 2003).

Generally, a regional tourist product is thus characterized by several elements:

a) constitution of specific spatial area (which is not necessarily the territory of the entire province, rather a homogeneous space, land, place) in which this product is produced;

b) uniqueness;

c) exclusivity associated with possessed qualities, the existence in a given area of material or immaterial resources. Complexity, complementarity and multivitability are also important (Zdon-Korzeniowska, 2009).

Therefore, a comprehensive regional product is a spatially defined, unique offer that "creates the possibility of choosing such a combination of elements that make up this product, that will create one specific bundle of benefits for the recipient" (Rogoziński, 2000). In this approach, emphasis is made on shaping the relevant product features, i.e. first it has to be determined what benefits the client expects, then the benefits for the company and finally the product features themselves, i.e. the components, form and presentation of the market offer.

\section{RESULTS}

There are several elements that determine the conditions for the development of regional tourist products. For the first, attention should be paid to spatial and natural conditions, including climate, in particular the occurrence of mountain range, lake, river, forest complex, access to the sea, which directly affects the attractiveness of the area and creates convenient opportunities for the development of tourist products. In addition, favorable technical infrastructure, relatively good quality of roads, sidewalks, access to sewage systems, developed gas and telecommunications networks, also affect the interest of potential buyers of products. Next to the "hard" infrastructure one cannot forget about the economic potential of a given place, i.e. the number and diversity of business entities, the quality of business environment institutions and social capital. Another element is good promotion, which fits in with the policy of central and local authorities, i.e. local government units. Among the promotional instruments, we can distinguish all publications of this nature, various folders, guides, participation in trade fairs, as well as the presence of a given unit and its representatives in the media (Kosmaczewska, 2013; Drab, 2011). A well-designed and constantly updated website of a given unit and the inhabitants' portal may be the decisive factors influencing the development of tourist products at the time of the development of information society.

In addition to the promotion, other activities of the communes and cities, which have various instruments classified as mechanisms of local intervention, are also important. They constitute a form of administrative coercion, economic and market influence, direct influence, infrastructure stimulation as well as information, educational and conceptual or organizational instruments (Kucharczyk, 2018). It is also possible to indicate the forms of planning and financial impact on development by local governments. The first group would include: the development strategy of the commune, spatial planning documents, multi-annual investment plans, multi-annual financial plans, local development plans, local revitalization programs, other plans and development programs. On the other hand, there are financial instruments including expenditure on infrastructure, culture, subsidies, and obtaining EU funds. The above-mentioned instruments are intended to stimulate entrepreneurship, vocational activation of residents, create new jobs and improve the quality of life both in the spatial dimension and in the natural or social dimensions (Majewska, 2012; Grabowska, 2014; Wojciechowski, 2012; Kogut-Jaworska, 2008). 
These conditions, including location, climatic and indirect ones, and above all the quantity and quality of economic and social infrastructure, influence directly the appearance of various tourist products. Expanding knowledge about a certain product depends equally on the creation of a network of inter-organizational links, which is understood as the increase of density of corporations, associations, local action groups or Euroregions in a given territory, promoting and financing or raising funds for specific projects, which are part of the development of tourist products.

In addition to the conditions, the policy of shaping the product is also important, covering all issues related to the product itself, and above all its features, functionalities, financing and promotion elements, in particular the naming, packaging and assortment structure of the product. The features that we give to the product should be adapted to the behavior and requirements of consumers, because this is a condition of its subsequent acceptance.

It is about giving the product in a comprehensive way:

1. basic features: heritage of the area, selected primary, basic elements, determining its tourist qualities, related to the core of the product;

2. complementary features: infrastructure, complementary, additional heritage, secondary elements, creating a certain set of tourist goods and services satisfying specific needs of tourists;

3. added value: it is the effect of the main idea, concept, creation, binding individual product elements, image, tools and stereotypes used in promotional activities (Stasiak \& Włodarczyk, 2003).

In addition to these components, when shaping the tourist product, its features, consisting of complexity, "multivitability" and complementarity should also be considered. In addition, it is the effect of the integrated operation of many entities creating the product, which reduces the costs of its preparation and promotion, increas- ing the chances of market success. There is no single fair price or standard, the construction of a regional product is associated with various costs resulting from the possibility of combining available services freely, and the consumption is spread over time. In addition, the regional tourist product is strongly dependent on several psychosocial factors, which are difficult to predict, i.e. the impact of fashion, goals, different motivations, individual habits, and negative trends (Stasiak \& Włodarczyk, 2003).

Considering the determinants of regional tourist products, the complexity of attributes and policies, it is worth to point out the entities that are responsible for shaping them. This group should include above all: producers, intermediaries, supporting and co-operating entities as well as clients whose functions are clearly defined. In the case of enterprises from the tourist industry, they are the main producers of goods and services, and besides, they create a material base of tourism, which is the basis for the functioning of tourist products. From the point of view of the subject of cooperation in the creation of tourist products, local authorities are an important supporter and coordinator of regional tourist products. They are responsible for creating the product idea, persuading others to implement it, especially in the case of local associations, entrepreneurs from complementary industries and the residents themselves (Adamowicz \& Wawrzyńczak, 2006). The role of the media, especially the local press, radio, performing an informational and promotional role, is equally important. In the long run, the "fourth power" participates in shaping attitudes and behavioral patterns and in building the image of the area and, of course, perpetuating the desired stereotypes.

All initiatives undertaken by these stakeholders must be approved by residents, hence it is important to carry out a preliminary calculation of not only the economic but also social and environmental costs. Undoubtedly, the local community is usually interested in the development of tourism enterprises, because it affects the increase of its income not only from the service of tourist traffic, but also within the complementary areas of business activity. A good example 
may be in the case of rural areas, the development of agritourism, significantly affecting the standard of living of people living on agricultural activities, or the development of small-scale production and handicrafts (Ignasiak-Szulc, 2009). As for tourists, they are rather consumers of the product, but their contribution manifests itself in the individual composing of individual tourist products, their promotion and advisory role (Stasiak \& Włodarczyk, 2003).

In general, there are two main approaches to create a tourist product. The first one has the character of an evolutionary process of developing a comprehensive brand product on the certain area. Originally, on the basis of the existing resources and qualities, various partial products, manufactured individually by various entities, arise in an uncoordinated way. With time, a formalized idea (concept) appears and subsequently leads to the combination of forces and resources in order to implement a joint venture and, based on the functioning tourist infrastructure, the mature form of a product with unique identity is created. In turn, the second method is the opposite to the first one - a certain area has some resources that can be used to create a product, but it has no infrastructure due to the fact that until now it was unnecessary. As a result, there are usually no tourist subproducts, so the development of tourism in this area begins only when the idea and concept of the product appear, for example, there may be an offer to develop agritourism. As shown in the presented methods, the final product is the result of marketing management of tourist resources of the area, which consists of combining available resources, forces and funds to create and prepare the most advantageous offer that will meet the needs of a specific group of clients (Stasiak \& Włodarczyk, 2003).

\section{DISCUSSION AND CONCLUSION}

Specified spatial regional tourist products may affect the increase of the level of development in a given territory. However, their creation depends to a large extent on the policy of local authorities, which may use various instruments affecting tourism.

In this article, the main goal was to show the essence and significance of the theme regional tourist products. These are mostly rural communes, municipalities, sets of settlement units, natural lands or, finally, clusters, other associations, and Euroregions unique in terms of their natural or anthropogenic qualities.

Another goal was to show the role of local authorities in influencing tourism. The role of entities responsible for the implementation of tourism policy, including entrepreneurs, animators and representatives of related industries, is also shown. Subsequently, the catalog of institutional, financial and promotional undertakings showing influence of the local authorities on tourism is indicated. The importance of territorial marketing as an important tool of communes and districts to build a common, complete tourist offer within the microregion is pointed out. One can not forget about the modernization of tourist infrastructure and the creation of new (and innovative) tourist products, due to the intensifying competition on the market and the creation of a cross-border cooperation network.

Considering the international conditions in general, the functioning of the national tourism policy system, as well as the social and economic issues, the regional tourism products will certainly play in the future an increasingly common role in promoting communes, districts and regions. Local authorities have many responsibilities in the area of promotion, attracting investments, obtaining funds or expanding the infrastructure. Many activities may serve in a direct or indirect way to create a regional tourist product related to a given settlement unit. 


\section{REFERENCES}

1. Adamowicz, M., \& Wawrzyńczak, E. (2006). Porozumienie Zielone Płuca Polski jako podstawa rozwoju wspótpracy transgranicznej. In K. Gomółka (Ed.), Wspótpraca transgraniczna a rozwój regionalny. Warszawa: Elbląg.

2. Basińska-Zych, A., \& LubowieckiVikuk, A. P. (2010). Interwencjonizm samorządowy w obszarze turystyki i rekreacji w wybranych państwach Unii Europejskiej. Acta Scientiarum Polonorum. Oeconomia, 9(4), 25-37. Retrieved from http://yadda.icm.edu.pl/yadda/ element/bwmeta1.element.ekonelement-000171189869

3. Drab, A. (2011). Marketing terytorialny $w$ gminie. A. Kożuch, M. Stych (Eds.). Częstochowa: Prawno-organizacyjne aspekty zarządzania gminą.

4. Drążkiewicz, J. (2009). Miejsce turystyki w zadaniach gminnego samorządu terytorialnego w Polsce. Rocznik Żyrardowski, 7, 265-286. Retrieved from http://mazowsze. hist.pl/29/Rocznik_Zyrardowski/659/2009/23620/

5. Gaworecki, W. W. (2003). Turystyka (424 p.). Warszawa: Polskie Wydawnictwo Ekonomiczne.

6. Grabowska, A. (2014). Władze samorzadowe jako podmiot ksztattujacy gospodarke turystyczna $w$ regionie (150 p.). Katowice: Uniwersytet Ekonomiczny w Katowicach. Retrieved from http://yadda.icm.edu.pl/yadda/ element/bwmeta1.element.ekonelement-000171273693

7. Herc, G. (2013). Samorząd terytorialny - pojęcie, istota i podstawy prawne. In M. Chmaj (Ed.), Prawo samorzadu terytorialnego. Warszawa: Polskie Wydawnictwo Ekonomiczne.

8. Ignasiak-Szulc, A. (2009). Rola turystyki w kreowaniu rozwoju gospodarczego i podnoszeniu konkurencyjności regionu. In R. Barcik \& G. Biesok (Eds.), Teoria i praktyka rozwoju lokalnego i regionalnego. Bielsko-Biała: Wydawnictwo Naukowe Akademii Techniczno-Humanistycznej.
9. Kaczmarek, J., Stasiak, A., \& Włodarczyk, B. (2005). Produkt turystyczny - pomyst, organizacja, zarządzanie. Warszawa: Polskie Wydawnictwo Ekonomiczne.

10. Kogut-Jaworska, M. (2008). Instrumenty interwencjonizmu lokalnego w stymulowaniu rozwoju gospodarczego (257 p.). Warszawa: CeDeWu.

11. Kosmaczewska, J. (2013). Turystyka jako czynnik rozwoju obszarów wiejskich (255 p.). Poznań: Bogucki Wydawnictwo Naukowe.

12. Krawczyszyn, N. (2011). Turystyczne marki „Citywalk” i „Fortfan” jako przykład transgranicznej współpracy sieciowej ["Citywalk" and "Fortfan" tourist brands as an example of transborder network co-operation]. Gospodarka przestrzenna, 240, 58-67. Retrieved from http://yadda.icm.edu.pl/yadda/ element/bwmeta1.element.ekonelement-000171215565

13. Kruczała, J. (1986). Zagospodarowanie turystyczne (78 p.). Kraków: Akademia Ekonomiczna.

14. Kruczek, Z., \& Sacha, S. (2001). Geografia atrakcji turystycznych Polski. Kraków: Proksenia.

15. Kucharczyk, K., \& Łajca, P. (2017). Zjawisko globalizacji we współczesnym świecie. Polonia Journal, 5-6, 115-130. Retrieved from https://www.researchgate. net/publication/328581102_ Zjawisko_globalizacji_we_wspolczesnym_swiecie

16. Majewska, J. (2012). Rola samorzadu terytorialnego $w$ kształtowaniu funkcji turystycznej gminy. Poznań: Wydawnictwo Uniwersytetu Ekonomicznego w Poznaniu.

17. Rogoziński, K. (2000). Nowy marketing ustug. Poznań: Wydawnictwo Akademii Ekonomicznej w Poznaniu.

18. Sala, K. (2016). Klastry jako forma współdziałania i innowacyjności na przykładzie Bieszczadzkiego Trangranicznego Klastra Turystycznego [Clusters as a Form of Cooperation and Innovation on the Example of the Bieszczady Cross-Border Tourism Cluster]. Zeszyty Naukowe Małopolskiej Wyższej Szkoły Ekonomicznej w Tarnowie, 32(4), 87-96. Retrieved from http://yadda.icm.edu.pl/ yadda/element/bwmeta1.element. ekon-element-000171457457

19. Stasiak, A., \& Włodarczyk, B. (2003). Produkt turystyczny - miejsce. Turyzm, 13/1, 55-80. Retrieved from http:// dspace.uni.lodz.pl:8080/xmlui/ bitstream/handle/11089/5000/ PT\%20-\%20MIEJSCE. pdf? sequence $=1$ \&isAllowed $=y$

20. Szromnik, A. (2008). Marketing terytorialny. Miasto i region na rynku. Kraków: Wolters Kluwer Business.

21. Wojciechowski, E. (2012). Zarzadzanie w samorzadzie terytorialnym (217 p.). Warszawa: Difin.

22. Zalech, M. (2010). Polityka turystyczna na szczeblu lokalnym - zakres, zadania, działania, determinant. Zeszyty Naukowe Uniwersytetu Szczecińskiego. Ekonomiczne Problemy Ustug, 53, 293-304.

23. Zdon-Korzeniowska, M. (2009). Jak kształtować regionalne produkty turystyczne? Teoria i praktyka (213 p.). Kraków: Wydawnictwo Uniwersytetu Jagiellońskiego. 